\title{
Nonomuraea sp. ID06-A0189 inulin fructotransferase (DFA III-forming): gene cloning, characterization and conservation among other Nonomuraea species
}

\author{
Sri Pudjiraharti ${ }^{1}$, Midori Ohtani ${ }^{2}$, Nanami Takano ${ }^{2}$, Ayumi Abe $^{2}$, Puspita Lisdiyanti ${ }^{3}$, Michiko Tanaka ${ }^{2}$, \\ Teruo Sone ${ }^{2}$ and Kozo Asano ${ }^{2}$
}

The inulin fructotransferase (DFA III-forming)(EC 4.2.2.18) gene in Nonomuraea sp. ID06-A0189 was amplified from genomic DNA, sequenced and expressed in Escherichia coli. The 1326-bp gene, designated as Nsp-ift, encodes a protein composed of a putative 37-amino-acid signal peptide and 404-amino-acid mature protein. A putative ribosomal binding sequence was identified 12 bases upstream from the start codon. However, a typical bacterial promoter could not be found by in silico analysis. The deduced amino-acid sequence of the enzyme was most similar to that of inulin fructotransferase (DFA I-forming) in Frankia sp. EAN1pec. Phylogenetic analysis of deduced amino-acid sequences indicated that Nonomuraea sp. ID06-A0189 and Frankia sp. EAN1pec inulin fructotransferases formed a distinct clade from those from Arthrobacter sp. H65-7,

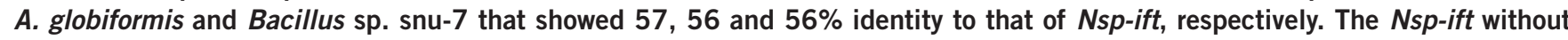
a putative signal peptide was successfully expressed in $E$. coli and partially purified using His-tag affinity chromatography. The recombinant enzyme displayed optimum temperature between 65 and $70^{\circ} \mathrm{C}$, optimum pH between 5.5 and 6.0 and remained stable up to $70^{\circ} \mathrm{C}$. The properties were identical to those of the original enzyme. Of 10 Nonomuraea species tested by Southern hybridization, enzyme activity measurements and PCR, only Nonomuraea sp. ID06-A0189 has the Nsp-ift gene, suggesting that $\mathbf{N s p - i f t}$ is not highly conserved in this genus.

The Journal of Antibiotics (2014) 67, 137-141; doi:10.1038/ja.2013.95; published online 16 October 2013

Keywords: gene structure; inulin fructotransferase gene; inverse PCR

\section{INTRODUCTION}

Inulin fructotransferase [EC 4.2.2.18], the enzyme that converts inulin into di-D-fructofuranose $1,2^{\prime}: 2,3^{\prime}$ dianhydride (DFA III) and a small amount of oligosaccharides, was initially discovered in Arthrobacter ureafaciens. ${ }^{1}$ The main product of this enzyme reaction, DFA III, was first established as a food ingredient for the prevention of osteoporosis because of its ability to stimulate calcium absorption in rats and humans. ${ }^{2-5}$ Subsequently, DFA III has been found to inhibit secondary bile acid formation in rats and humans, ${ }^{6-7}$ thus it is also a good candidate for use as a prebiotic for the prevention of colon cancer. The health benefits of DFA III make inulin fructotransferase (DFA III-forming) an important enzyme for the food industry. Japan has used it for industrial production of DFA III since $2004 .^{8}$

To date, inulin fructotransferases from species of Arthrobacter, ${ }^{9-13}$ Bacillus, ${ }^{14}$ and Leifsonia ${ }^{15}$ have been studied, the corresponding genes from three of them have been cloned and expressed in heterologous hosts. ${ }^{16-18}$ For a better understanding of this enzyme in another genus, the gene that encodes inulin fructotransferase in Nonomuraea sp.
ID06-A0189 was characterized and expressed in this study. Previously, we selected and described Nonomuraea sp. ID06-A0189 that could produce inulin fructotransferase (DFA III-forming) in the culture broth. ${ }^{19}$ The crude enzyme showed promising characteristics for mass production of DFA III. The objectives of this work were to clone and express the gene that encodes inulin fructotransferase in Nonomuraea sp. ID06-A0189 and to compare it to previously studied genes. In addition, we used Southern hybridization and PCR to determine whether this gene is conserved among other members of the genus Nonomuraea. This study will provide molecular aspects of the enzyme and aid in improving mass production of DFA III.

\section{MATERIALS AND METHODS}

Bacterial strains and culture condition

This study used 10 different species of the genus Nonomuraea. One, Nonomuraea sp. ID06-A0189, was isolated from Indonesian soil ${ }^{20}$ and the other nine type strains for Nonomuraea species, N. africana JCM $3109^{\mathrm{T}}$, N. ferruginea JCM $3283^{\mathrm{T}}$, N. fastidiosa JCM $3321^{\mathrm{T}}$, N. longicatena JCM $11136^{\mathrm{T}}$,

${ }^{1}$ Research Centre for Chemistry, Indonesian Institute of Sciences, JI. Sangkuriang, Bandung, Indonesia; ' Laboratory of Applied Microbiology, Graduate School of Agriculture, Hokkaido University, Sapporo, Hokkaido, Japan and ${ }^{3}$ Research Centre for Biotechnology, Indonesian Institute of Sciences, Jl. Raya Bogor KM 46, Cibinong, Bogor, Indonesia Correspondence: Dr T Sone, Graduate School of Agriculture, Hokkaido University, Laboratory of Applied Microbiology, Kita 9, Nishi 9, Kita-ku, Sapporo, Hokkaido 060-8589, Japan. 
N. polychroma JCM $6834^{\mathrm{T}}, N$. pusilla JCM $3144^{\mathrm{T}}, N$. roseoviolaceae subsp. carminata JCM $9946^{\mathrm{T}}, N$. roseoviolaceae subsp. roseoviolaceae JCM $3145^{\mathrm{T}}$ and N. rubra JCM $3234^{\mathrm{T}}$, were purchased from the Japan Collection of Microorganisms (JCM). These type strains were chosen because they represented different clades of the Nonomuraea phylogenetic tree. ${ }^{19}$ Nonomuraea sp. ID06-A0189 was maintained on International Streptomyces Project 2 agar medium ${ }^{21}$ and incubated at $30^{\circ} \mathrm{C}$ for 7 days, whereas the strains from the JCM were cultured according to their catalog. For DNA extraction, the strains were cultivated in International Streptomyces Project 2 liquid medium at $30{ }^{\circ} \mathrm{C}$ with shaking of 150 r.p.m. for 3 days. The cells were collected by centrifugation $(8000 \times g, 20 \mathrm{~min})$ and washed twice with $0.95 \% \mathrm{NaCl}$ solution Total genomic DNA was extracted using the ISOPLANT II DNA extraction kit (Nippon Gene, Tokyo, Japan) according to the manufacturer's instruction.

\section{Amplification of inulin fructotransferase gene partial fragments} For PCR amplification of inulin fructotransferase genes from Nonomuraea sp. ID06-A0189, conserved regions of the known inulin fructotransferase genes from A. globiformis C11-1 (D38528), Arthrobacter sp. H65-7 (D84399), Bacillus sp. (DQ112363) and Frankia sp. (CP000820) were used to design forward and reverse primers named N4F and N7R, respectively (Table 1). To determine the conservation of Nsp-ift among the genus Nonomuraea by PCR, N4F and N7R primers were used to amplify inulin fructotransferase genes of the 10 chosen Nonomuraea strains. PCR was performed in $50 \mu \mathrm{l}$ reaction mixtures using the Colorless GoTaq Flexi PCR Kit (Promega, Madison, WI, USA) according to the protocol provided. PCR was performed in a Gene Amp PCR system 9600 (Applied Biosystems, Foster City, CA, USA) thermal cycler. The PCR consisted of an initial denaturation at $95^{\circ} \mathrm{C}$ for $90 \mathrm{~s}$ then 30 cycles of $95^{\circ} \mathrm{C}$ for $15 \mathrm{~s}, 55^{\circ} \mathrm{C}$ for $30 \mathrm{~s}$ and $72^{\circ} \mathrm{C}$ for $50 \mathrm{~s}$. The PCR product was purified using a SUPRECPCR Kit (Takara Bio Tokyo, Japan) and sequenced using the ABI Prism Big Dye Terminator V1.1 Cycle Sequencing Kit (Applied Biosystems) and ABI 3100 DNA sequencer (Applied Biosystems). The obtained data were analyzed using an Auto assembler software from Applied Biosystems.

\section{Inverse PCR and bioinformatics analysis}

Genomic DNA of Nonomuraea sp. ID06-A0189 was digested with Kpn (Takara Bio, Ohtsu, Japan), and self-ligated using T4 DNA ligase (NEB, Ipswich, MA, USA). The ligated product was used as template for inverse PCR using primers F1 and R1 (Table 1), which were designed based on the partial sequence of inulin fructotransferase genes of Nonomuraea sp. ID06-A0189 obtained by PCR. Inverse PCR was conducted using a KOD-FX Kit (Toyobo, Osaka, Japan) according to the protocol provided. Thermal cycler conditions used were initial denaturation at $94{ }^{\circ} \mathrm{C}$ for 2 min followed by 5 cycles at $98{ }^{\circ} \mathrm{C}$ for $10 \mathrm{~s}$ and $74^{\circ} \mathrm{C}$ for $6 \mathrm{~min} ; 5$ cycles at $98^{\circ} \mathrm{C}$ for $10 \mathrm{~s}$ and $72^{\circ} \mathrm{C}$ for $6 \mathrm{~min} ; 5$ cycles at $98^{\circ} \mathrm{C}$ for $10 \mathrm{~s}$ and $70^{\circ} \mathrm{C}$ for $6 \mathrm{~min} ; 25$ cycles at $98^{\circ} \mathrm{C}$ for $10 \mathrm{~s}$ and $68^{\circ} \mathrm{C}$ for $6 \mathrm{~min}$ and $68^{\circ} \mathrm{C}$ for $7 \mathrm{~min}$. The inverse PCR products were purified using a SUPREC-PCR Kit (Takara Bio) and sequenced using a primer-walking strategy. The fragment sequences were assembled using Auto Assembler software (Applied Biosystems) and analyzed using Genetyx-MAC (Genetyx, Tokyo, Japan). The signal peptide cleavage site in the deduced amino-acid sequence was predicted using SignalP-3.0.22 BLAST was used to compare of the deduced amino-acid sequence to those in the NCBI database. The phylogenetic tree was constructed using the neighbor-joining method in CLUSTAL X.

\section{Cloning and expression of inulin fructotransferase gene}

Primers pETIFTF2 (5'-GGGGAATTCGCAGGCCGGGCCGTCCA- $\left.3^{\prime}\right)$ and pETIFTR2 (5'-GGGGCGGCCGCTCAGGGAGTGGCGCGGA-3') were used

Table 1 Primers used for PCR reaction

\begin{tabular}{lll}
\hline Name & Sequence & Forward/reverse \\
\hline N4F & 5'CGACAACWTSATCGCCGAATG-3' $^{\prime}$ & Forward \\
N7R & 5'-GAVGCBGKGSCGCTGTC-3' & Reverse \\
F1 & 5'-CACGCGAGGCACGAAGGTG-3' & Forward \\
R1 & 5'-CCCGCGCCGACATGGTT-3' & Reverse \\
\hline
\end{tabular}

to amplify the gene that encodes the mature protein of inulin fructotransferase. PCR was performed in $50 \mu \mathrm{l}$ reaction mixtures using the Colorless GoTaq Flexi PCR Kit (Promega) according to the protocol provided. PCR was performed in a Gene Amp PCR system 9600 (Applied Biosystems) thermal cycler. The PCR consisted of an initial denaturation at $95^{\circ} \mathrm{C}$ for $90 \mathrm{~s}$ then 30 cycles of $95^{\circ} \mathrm{C}$ for $15 \mathrm{~s}, 55^{\circ} \mathrm{C}$ for $30 \mathrm{~s}$ and $72^{\circ} \mathrm{C}$ for $50 \mathrm{~s}$. The PCR product was gel purified using the Wizard SV Column Kit (Promega). The purified PCR product and the vector pET28(b) (Merck, Darmstadt, Germany) were digested with EcoRI and NotI, and ligated with T4 DNA ligase (NEB). The recombinant plasmid (pETIFT) was introduced into E. coli BL21(DE3). The transformant was cultured in Luria-Bertani liquid medium containing $50 \mu \mathrm{g} \mathrm{ml}^{-1}$ kanamycin with shaking at $37^{\circ} \mathrm{C}$ and Nsp-ift was induced with isopropyl $\beta$-D-thiogalactoside at a final concentration of $0.1 \mathrm{~mm}$, during $\mathrm{OD}_{600}$ was $0.4-0.6$. Following additional shaking cultivation at $30^{\circ} \mathrm{C}$ for $24 \mathrm{~h}$, cells were harvested by centrifugation. Cell-free extract was obtained by beads disruption and purified with His-tag affinity chromatography (HisTrap HP, GE Healthcare, Buckinghamshire, UK). Fractions were desalted with Econo-Pac 10DG (Bio-Rad, Hercules, CA, USA) and used for inulin fructotransferase activity assay.

\section{Production of inulin fructotrasferase and measurement of enzyme activity}

Single colony of each type strain of Nonomuraea was inoculated into $10 \mathrm{ml}$ of inulase induction medium, containing $10 \mathrm{~g}$ inulin, $2 \mathrm{~g} \mathrm{NaNO}_{3}, 0.5 \mathrm{~g} \mathrm{MgSO}_{4} 7$ $\mathrm{H}_{2} \mathrm{O}, 0.5 \mathrm{~g} \mathrm{KCl}, 0.01 \mathrm{~g} \mathrm{FeSO}_{4} 7 \mathrm{H}_{2} \mathrm{O}, 0.2 \mathrm{~g}$ yeast extract and $0.5 \mathrm{~g} \mathrm{KH}_{2} \mathrm{PO}_{4}$ per liter ( $\mathrm{pH}$ 7.0) and incubated at $30^{\circ} \mathrm{C}$ with shaking ( 140 r.p.m.) for 5 days. The culture was centrifuged to remove the biomass and the supernatant was assayed for its inulin fructotransferase activity. Culture supernatant $(0.5 \mathrm{ml})$ was mixed with $0.5 \mathrm{ml}$ of $10 \%$ inulin solution in $20 \mathrm{~mm}$ citric acid- $\mathrm{NaOH}$ buffer ( $\mathrm{pH}$ 5.6) and incubated at $60^{\circ} \mathrm{C}$ for $1 \mathrm{~h}$ then boiled in a water bath for $5 \mathrm{~min}$ to stop the reaction. The reaction mixture was applied to a TLC silica gel plate (Merck) and exposed to a mixture of 1-butanol-2-propanol-water (10: 5: $4, \mathrm{v} / \mathrm{v})$. DFA III spot was detected by spraying with $p$-anisaldehyde- $\mathrm{H}_{2} \mathrm{SO}_{4-}$ ethanol (1: 1: 18, v/v) followed by heating at $120^{\circ} \mathrm{C}$ for $30 \mathrm{~s}$. One unit of enzyme activity is defined as the amount of enzyme that produces $1 \mu \mathrm{mol}$ of DFA III per minute at $65^{\circ} \mathrm{C}$ and at a pH of 5.5 in $10 \mathrm{~min}$.

\section{Inulin fructotransferase gene detection in Nonomuraea species by} Southern hybridization

To determine the conservation of Nsp-ift among the genus Nonomuraea, genomic DNA of the 10 chosen Nonomuraea strains were digested with EcoRV ClaI, KpnI and SmaI (Takara Bio), separated in a $1 \%(w / v)$ agarose gel then blotted onto a Hybond- $\mathrm{N}^{+}$membrane (GE Healthcare, Buckinghamshire, UK) according to the manufacturer's protocol. Hybridization was performed using the AlkPhos Direct Labeling and Detection System using the CDP-Star detection (GE Healthcare). The hybridization probe was prepared from the partial inulin fructotransferase gene of Nonomuraea sp. ID06-A0189 obtained by PCR. To obtain sufficient probe DNA, before labeling, the PCR fragment was cloned using the pGEMT-easy vector system according to the manufacturer's instructions (Promega). Hybridization and subsequent membrane washing were conducted at $62^{\circ} \mathrm{C}$. When the probe did not hybridize, the temperatures were lowered to $55^{\circ} \mathrm{C}$ to increase sensitivity. Hybridization signals were detected using a Luminescent Image Analyzer LAS-400 (Fuji Film, Tokyo, Japan).

\section{RESULTS AND DISCUSSION}

Molecular cloning and characterization of inulin fructotransferase gene

Primers N4F and N7R, which were designed based on the conserved regions of previously reported inulin fructotransferase (DFA IIIforming) genes, ${ }^{16-18}$ produced a PCR product from Nonomuraea sp. ID06-A0189 with the expected size $(\sim 600 \mathrm{bp})$ based on the inulin fructotransferase gene of Arthrobacter sp. H65-7 (Figure 1a). This partial fragment was designated as NSP17 and the highest identity of the deduced amino-acid sequence was $72 \%$ to Frankia sp. EAN1pec 
inulin fructotransferase (DFA I-forming). Hybridization of a labeled probe made from this fragment to Nonomuraea sp. ID06-A0189 genomic DNA indicated that the gene was carried on EcoRV- and ClaI-digested DNA fragments $\sim 8.5-9.0 \mathrm{~kb}, 6.0 \mathrm{~kb} K p n \mathrm{I}$ fragment and $3.0 \mathrm{~kb}$ (the strong band) SmaI fragment (Figure1b). A second weak hybridization band in SmaI-digested DNA was likely a nonspecific signal resulting from the low stringency temperatures used for hybridization and washing, $55^{\circ} \mathrm{C}$. The $6.0-\mathrm{kb} K p n \mathrm{I}$ fragment was large enough to contain the whole inulin fructotransferase a

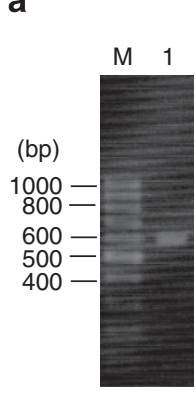

b

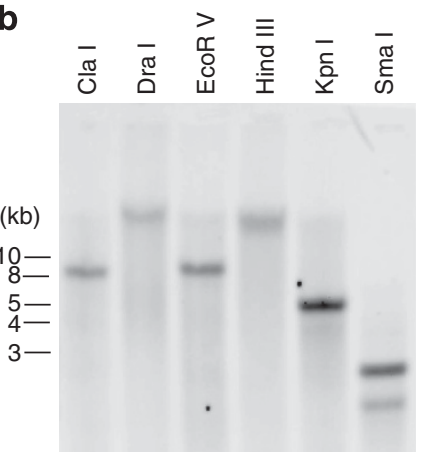

c

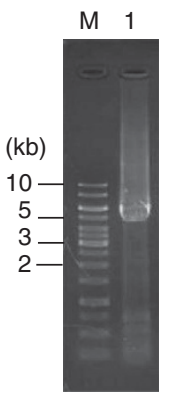

Figure 1 Amplification of inulin fructotransferase gene from Nonomuraea sp. ID06-A0189. (a) Amplification of partial inulin fructotransferase gene from genomic DNA of Nonomuraea sp. ID06-A0189. (lane 1); M indicates 100 bp DNA ladder, (b) Southern hybridization of Nonomuraea sp. ID06A0189 genomic DNA using the inulin fructotransferase gene fragment (NSP17) as a probe. The restriction enzyme used for digestion of genomic DNA is indicated above each lane, (c) inverse PCR product amplified from Kpnl-digested chromosomal DNA. (lane 1); M indicates 1 kbp DNA ladder. gene, therefore, $K p n I$ was chosen for genomic DNA digestion for inverse PCR.

Inverse PCR produced a 6.0-kb fragment that corresponded to the 6.0-kb KpnI fragment identified by hybridization (Figure 1c). A total of $1665 \mathrm{bp}$ of sequence for the fragment was obtained. A 1326-bp open reading frame appeared to code the inulin fructotransferase gene. This open reading frame encoded a protein composed of a putative 37-amino acids signal peptide for secretion and a 404-amino acids mature protein. A putative ribosomal binding sequence, AGGAGG, was identified 12 bases upstream from the start codon. However, typical bacterial promoter sequences were not found upstream of the ribosomal binding sequence by in silico analysis. This open reading frame was named Nsp-ift, for the Nonomuraea sp. putative inulin fructotransferase gene. The nucleotide sequence of Nsp-ift has been deposited in the GenBank database under accession number AB775898.

Sequence similarity comparisons indicated that the deduced amino-acid sequence of $N$ sp-ift was $72 \%$ identical to inulin fructotoransferase in Frankia sp. EAN1pec. It was less similar to the deduced sequences from Arthrobacter sp. H65-7 (BAA18967.1), A. globiformis and Bacillus sp. snu-7 with 57, 56 and 56\% identity, respectively. The lowest sequence similarity $54 \%$ was to Arthrobacter sp. H65-7 (BAD06469.1). The sequence identity among these inulin fructotransferases provides a means to determine interaction between active sites and substrates as well as the circulation mechanism of the difructose moiety as proposed by Jung et al. ${ }^{23}$ Two amino-acid residues, Asp-233 and Glu-244 that were identified in Bacillus sp. snu7 inulin fructotransferase (DFA III-forming), were predicted to have important roles in the cleavage of glycosidic linkage between the difructose moiety to adjacent fructose unit in the formation of dioxane ring of DFA III. Both residues were identified as strictly

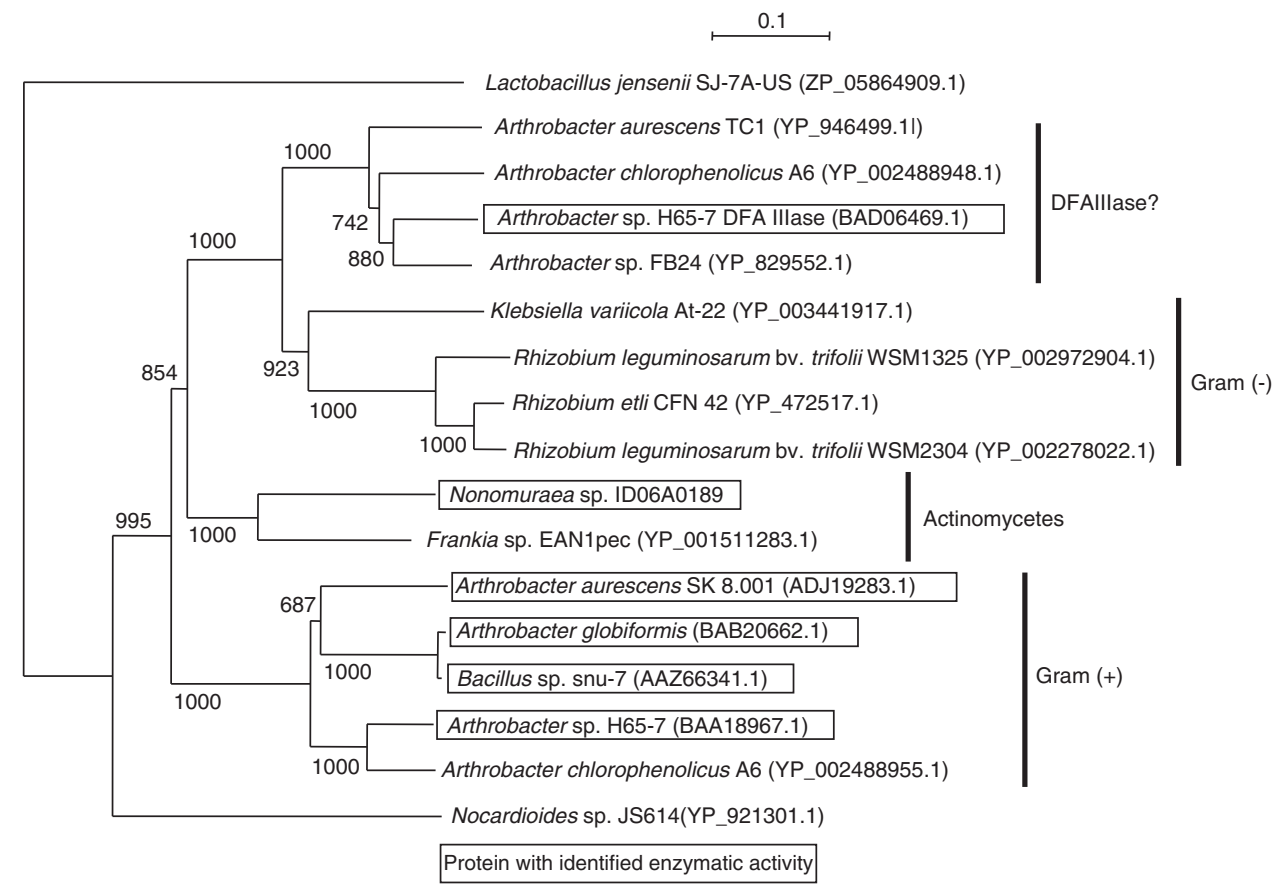

Figure 2 A neighbor-joining phylogenetic tree based on amino-acid sequences of known inulin fructotransferases and putative enzymes annotated in genome analyses of other bacterial species. Amino-acid sequences of Nonomuraea sp. ID06-A0189 and other enzymes are aligned and a neighbor-joining tree was constructed without sequence positions with gaps. Accession numbers are indicated in parentheses after sequence names. Bootstrap values calculated on 1000 iterations were indicated on corresponding clades. Known enzymes with identified activity are indicated by boxes. Clade names are indicated on the right side of corresponding clades. 
conserved sequences (data not shown) in all five known enzymes (marked with boxes), as shown in Figure 2.

Phylogenetic analysis indicated that the deduced inulin fructotansferases and related sequences made four distinct clades (Figure 2). The putative Nsp-ift protein sequence made a distinct clade with the deduced inulin fructotransferase (DFA I-forming) of Frankia sp. EAN1pec. The other previously studied inulin fructotansferases made a second clade with the exception of Arthrobacter sp. H65-7 a
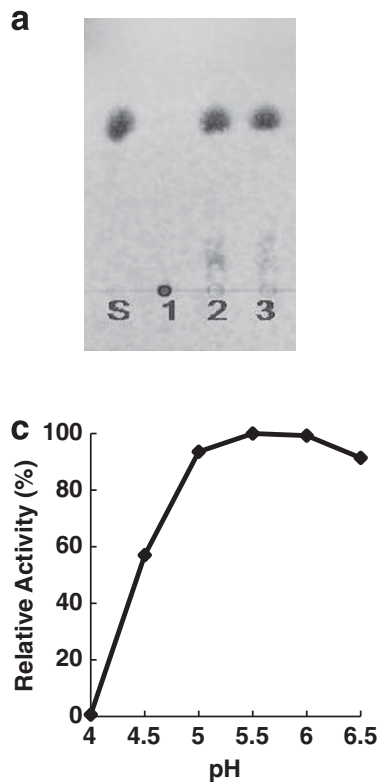
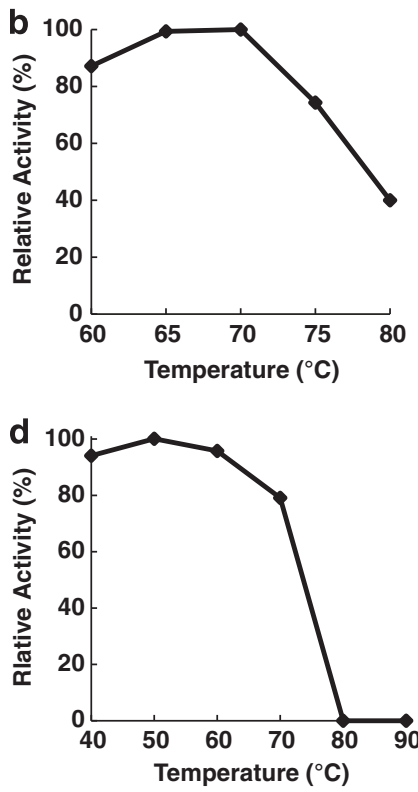

Figure 3 Activity of Nonomuraea sp. ID06-A0189 recombinant inulin fructotransferase. (a) Thin-layer chromatogram of enzyme reaction product from inulin. S indicates DFA III standard; 1 Inulin reacted with crude extract of $\mathrm{pET} 28$ (b) blank vector for $10 \mathrm{~min}$; 2 Inulin reacted with crude extract of recombinant Nonomurea sp. ID06-A0189 inulin fructotransferase for $10 \mathrm{~min}$; 3 Inulin reacted with purified recombinant Nonomurea sp. ID06-A0189 inulin fructotransferase for $10 \mathrm{~min}$. (b) Effect of temperature on enzyme activity. The enzyme reaction was performed in $10 \mathrm{~mm}$ citric acid- $\mathrm{NaOH}$ buffer at a $\mathrm{pH}$ of 5.6 , at temperatures ranging from $60-80^{\circ} \mathrm{C}$ for $1 \mathrm{~h}$. (c) Effect of $\mathrm{pH}$ on enzyme activity. The enzyme reaction was performed at different $\mathrm{pH}$ values $(4.0-6.5)$ at $65^{\circ} \mathrm{C}$ for $1 \mathrm{~h}$. (d) Thermal stability of enzyme. The enzyme was heated to various temperatures (40$90^{\circ} \mathrm{C}$ ) for $20 \mathrm{~min}$. The residual activity was measured at $65^{\circ} \mathrm{C}$ and $\mathrm{pH}$ of 5.5 for $1 \mathrm{~h}$. Relative activity (\%) for optimum $\mathrm{pH}$ and temperature was calculated based on the highest enzyme activity, which is shown as $100 \%$ of the relative activity. For thermal stability, the residual activity was compared with the activity before heating.
(BAD06469.1) that made a third clade with hypothetical enzymes found in the genomes of other Arthrobacter species. These three Arthrobacter enzymes were identified only by sequence annotation and not functionally tested; however, because of their sequence similarity, it is possible that they have DFA IIIase activity. The fourth clade consists of four hypothetical enzymes from Gram-negative bacteria, in which inulin fructotransferase has not been reported. Existence of a similar gene in Rhizobium species is interesting for future studies on the potential role of inulin fructotransferase-related genes in plant-microbe interactions. The deep branching of the deduced Nsp-ift amino-acid sequence from other inulin fructotransferases $^{16-18}$ indicates the distinction of Nsp-ift protein primary structure that contributes to its greater DFA IIIase activity. This makes it ideal for the development of DFA III production by accumulation in the medium along with the observation that Nonomuraea sp. ID 06-A0189 does not assimilate DFA III as carbon source.

\section{Expression, purification and properties of recombinant inulin} fructotransferase

The recombinant enzyme without a signal sequence was expressed in E. coli BL21(DE3) and the cell-free extract produced DFA III from inulin (Figure 3a) with enzyme activity of $543 \mathrm{Uml}^{-1}$. This value was ninefold higher than that produced by the wild strain $\left(60.3 \mathrm{U} \mathrm{ml}^{-1}\right) .{ }^{19}$ Purification using His-tag affinity chromatography increased the purity of recombinant enzyme two fold higher than that of its crude extract with specific activity of $1991 \mathrm{U}$ per mg protein. The purity was confirmed by SDS-PAGE, in which even though many other protein bands still existed, the major band corresponding to inulin fructotransferase was clearly observed with an estimated MW of $43 \mathrm{kDa}$ (data not shown).

Optimal activity of the purified recombinant enzyme was observed over a temperature range of $65-70{ }^{\circ} \mathrm{C}$ (Figure $3 \mathrm{~b}$ ) and a $\mathrm{pH}$ range of 5.5-6.0 (Figure 3c). The enzyme was stable up to $70{ }^{\circ} \mathrm{C}$ and retained $79 \%$ its activity after treatment for $20 \mathrm{~min}$ (Figure 3d). Those properties were almost identical to those of the native enzyme ${ }^{19}$ and generally did not significantly differ from other similar enzymes (Table 2). The recombinant enzyme showed somewhat higher activity at sub-optimum $\mathrm{pH}$ as compared with the native enzyme but this might be due to the influence of contaminated protein in the native enzyme, which was characterized as crude enzyme. $^{19}$ As can be seen in Table 2, the production level of recombinant inulin fructotransferase from Nonomuraea sp. ID-A0189 was higher than those of other similar enzymes reported from Arthrobacter sp. H65-7 (180000 U 1 $\left.{ }^{-1}\right),{ }^{16}$ A. globiformis C11-1 $\left(1500 \mathrm{Ul}^{-1}\right)^{17}$ and $A$. aurescens SK $8.001\left(81000 \mathrm{Ul}^{-1}\right) .^{24}$

Table 2 Properties of recombinant inulin fructotransferases from Nonomuraea sp. ID-06A0189 and other bacteria

\begin{tabular}{|c|c|c|c|c|c|c|}
\hline \multirow[b]{2}{*}{ Microorganism } & \multirow[b]{2}{*}{ Enzyme activity $\left(U I^{-1}\right)$} & \multirow[b]{2}{*}{ Optimal pH } & \multirow[b]{2}{*}{ Optimal temperature $\left({ }^{\circ} \mathrm{C}\right)$} & \multicolumn{2}{|c|}{ Thermostability } & \multirow[b]{2}{*}{ Reference } \\
\hline & & & & $\left({ }^{\circ} \mathrm{C}\right)$ & Time (min) & \\
\hline Nonomuraea sp. ID-A0189 & 543000 & $5.5-6.0$ & $65-70$ & 70 & 20 & This work \\
\hline Arthrobacter sp. H65-7 & 180000 & & & & & Yokota et al. ${ }^{11}$ \\
\hline Arthrobacter sp. A-6 & & 6.0 & 70 & 70 & 300 & Kim et al. 25 \\
\hline A. globiformis C11-1 & 1500 & 5.0 & $50-60$ & 75 & & Haraguchi et al. ${ }^{17}$ \\
\hline Bacillus sp. snu-7 & 1735000 & $5.5-6.0$ & 40 & 60 & 10 & Kim et al. ${ }^{18}$ \\
\hline A. aurescens SK 8.001 & 81000 & 6.0 & 55 & 60 & 240 & Zhao et al. ${ }^{24}$ \\
\hline
\end{tabular}


Even though the production level of Nonomuraea sp. ID-A0189 recombinant inulin fructotransferase was lower than that produced by Bacillus sp. snu-7, the thermostability was higher. Because of high thermostability and conversion yield, ${ }^{19}$ this enzyme can be applied for the production of DFA III in large scale where inulin fructotransferase with high activity is needed. This expression system seems appropriate for satisfying this need. Besides that, information on characteristics of the purified recombinant enzyme is necessary for optimization of DFA III production to get high conversion yield. Further, for more efficient and massive production of this intracellular recombinant enzyme, development of fermentation process and technology is required.

As shown in Figure 3, it seems that fructose was not produced from inulin by the enzyme. In our previous work, we found that the native crude enzyme not only converted inulin into DFA III (the major product) and small amounts of 1-kestose (GF2), 1-nystose (GF3) and 1 -fructosylnystose (GF4) but also a very small amount of fructose. ${ }^{19}$ This finding suggested that the strain might also secrete other inulindegrading enzyme to produce fructose. Thus, removing the inulindegrading gene by cloning technology increased productivity of inulin fructotransferase.

\section{Conservation of Nsp-ift among Nonomuraea species}

Conservation of Nsp-ift among Nonomuraea species was investigated by Southern hybridization and PCR amplification of ift gene and enzyme activity measurements. All results indicated that Nsp-ift was present in Nonomuraea sp. ID06-A0189 but none of the other Nonomuraea species tested. This finding indicates that Nsp-ift is a specific gene in Nonomuraea sp. ID06-A0189.

In conclusion, inulin fructotransferase from Nonomuraea sp. IDA0189 was cloned and characterized in this study. The gene indicated weak DFA IIIase activity that makes it possible for the development of DFA III production by accumulation in the medium and the enzyme has potential properties for large-scale production of DFA III. Further study on this enzyme should contribute for molecular characterization of the enzymatic reaction and efficient production of DFA III.

\section{ACKNOWLEDGEMENTS}

This work was supported by the Japan Society for Promotion Science for Ronpaku Program and the Government of Indonesia through the DIPA Project of the Indonesian Institute of Sciences, Year 2011. We thank Dr Yantyati Widyastuti and Dr Katsuhiko Ando for providing cultures from the Joint Research Project between Indonesian Institute of Sciences (LIPI), representing the Government Research Center (GRC) of the Republic of Indonesia and National Institute of Technology and Evaluation (NITE) of Japan. We are grateful to Professor Cindy H. Nakatsu at Purdue University, for editing the English language and for the valuable critical reading of the manuscript.
1 Uchiyama, T., Niwa, S. \& Tanaka, K. Purification and properties of Arthrobacter ureafaciens inulase II. Biochim. Biophys. Acta. 315, 412-420 (1973).

2 Suzuki, T., Hara, H., Kasai, T. \& Tomita, F. Effects of difructose anhydride III on calcium absorption in small and large intestines of rats. Biosci. Biotechnol. Biochem. 62, 837-841 (1998).

3 Mineo, H., Hara, H., Shigematsu, N., Okuhara, Y. \& Tomita, F. Melibiose, difructose anhydride III and difructose anhydride IV enhance net calcium absorption in rat small and large intestinal epithelium by increasing the passage of tight junctions in vitro. J. Nutr. 132, 3394-3399 (2002).

4 Mitamura, R., Hara, H., Aoyama, Y. \& Chiji, H. Supplemental feeding of difructose anhydride III restores calcium absorption impaired by ovariectomy in rats. J. Nutr. 132, 3387-3393 (2002).

5 Shigematsu, N., Okuhara, Y., Shiomi, T., Tomita, F. \& Hara, H. Effect of difructose anhydride III on calcium absorption in humans. Biosci. Biotechnol. Biochem. 68, 1011-1016 (2004).

6 Minamida, K. et al. Effects of difructose anhydride III (DFA III) administration on bile acids and growth of DFA III-Assimilating bacterium Ruminococcus productus on rat intestine. J. Biosci. Bioeng. 99, 548-554 (2005)

7 Minamida, K. et al. Effects of long-term ingestion of difructose anhydride III (DFA III) on intestinal bacteria and bile acid metabolism in humans. J. Biosci. Bioeng. 101, 149-156 (2006).

8 Kikuchi, H. et al. Industrial production of difructose anhydride III (DFA III) from crude inulin extracted from chicory roots using Arthrobacter sp. H65-7 fructosyl transferase. J. Biosci. Bioeng. 107, 262-265 (2009).

9 Kawamura, M., Takahashi, S. \& Uchiyama, T. Purification and some properties of inulin fructotransferase (depolymerizing) from Arthrobacter ilicis. Agric. Biol. Chem. 52, 3209-3210 (1988).

10 Haraguchi, K. et al. Purification and properties of inulin fructotransferase (depolymerizing) from Arthrobacter globiformis C11-1. Agric. Biol. Chem. 52, 291-292 (1988).

11 Yokota, A. et al. Production of inulin fructotransferase (depolymerizing) by Arthrobacter sp. H65-7 and preparation of DFA III from inulin by the enzyme. J. Ferment. Bioeng. 72, 258-261 (1991).

12 Haraguchi, K., Yamanaka, T. \& Ohtsubo, K. Purification and properties of a heat stable inulin fructotransferase (DFA III-producing) from Arthrobacter pascens T13-2. Carbohyd. Polym. 50, 117-121 (2002).

13 Haraguchi, K., Yoshida, M. \& Ohtsubo, K. Thermostable inulin fructotransferase (DFA III-producing) from Arthrobacter sp. L68-1. Carbohyd. Polym. 59, 411-416 (2005).

14 Kang, S., Kim, W. Chang, Y. \& Kim, S. Purification and properties of inulin fructotransferase (DFA III-producing) from Bacillus sp. snu-7. Biosci. Biotechnol. Biochem. 62, 628-631 (1998)

15 Haraguchi, K., Yoshida, M. \& Ohtsubo, K. Inulin fructotransferase (DFA III-producing) from Leifsonia sp. T88-4. Carbohyd. Polym. 66, 75-80 (2006).

16 Sakurai, H., Yokota, A. \& Tomita, F. Molecular cloning of an inulin fructotransferase (depolymerizing) gene from Arthrobacter sp. H65-7 and its expression in Escherichia coli. Biosci. Biotechnol. Biochem. 61, 87-92 (1997).

17 Haraguchi, K., Mori, S. \& Hayashi, K. Cloning of inulin fructotransferase (DFA IIIproducing) gene from Arthrobacter globiformis C11-1. J. Biosci. Bioeng. 89, 590-595 (2000).

$18 \mathrm{Kim}, \mathrm{C}$.-S. et al. Cloning, expression, and characterization of Bacillus sp. snu-7 inulin fructotransferase. J. Microbiol. Biotechnol. 17, 37-43 (2007).

19 Pudjiraharti, S. et al. Actinomycete Nonomuraea sp. isolated from Indonesian soil is a new producer of inulin fructotransferase. J. Biosci. Bioeng. 111, 671-674 (2011).

20 Widyastuti, Y. \& Ando, K. Final Report on Joint Research Project on Taxonomic and Ecological Studies of Fungi and Actinomycetes in Indonesia (2010).

21 Shirling, E.B. \& Gottlieb, D. Methods for characterization of Streptomyces species. Int. J. Syst. Bacteriol. 16, 313-340 (1966).

22 Bendtsen, J. D., Nielsen, H., Heijne, G.V. \& Brunak, S. Improved prediction of signal peptides: SignalP 3.0. J. Mol. Biol. 340, 783-795 (2004).

23 Jung, W. S. et al. Structural and functional insights into intramolecular fructosyltransfer by inulin fructotransferase. J. Biol. Chem. 282, 8414-8423 (2007).

24 Zhao, M. et al. Cloning and extracellular expression of inulin fructotransferase from Arthrobacter aurescens SK 8.001 in E. coli. J. Sci. Food Agric. 91, 2715-2721 (2011).

25 Kim, H.-Y., Kim, C.-W. \& Choi, Y.-J. Cloning and expression of inulin fructotransferase gene of Arthrobacter sp. A-6 in Escherichia coli and Bacillus subtilis. J. Microbiol. Biotechnol. 10, 275-280 (2000). 